\title{
Effects of Lactobacillus casei Culture Supernatant on Differentiation of 1552 Cell \\ Line
}

\section{Kazem Maftuni (MSc)}

Department of Microbiology, Faculty of Biology, Islamic Azad University, Ahar Branch, Ahar, Iran

Peyman Zare (PhD)

Department of Pathobiology, Faculty of Veterinary Medicine, University of Tabriz, Tabriz, Iran

Corresponding author: Kazem Maftuni

Email: maftun1351@yahoo.com

Tel: +989144159252

Address: Faculty of Biology, Islamic Azad University, Ahar Branch, Ahar, Iran

Received : 26 May 2015

Revised: 01 Jul 2015

Accepted: $04 \mathrm{Jul} 2015$

\section{ABSTRACT}

Background and objective: Considering the toxic side effects of chemotherapy in treatment of cancer, anticancer drugs of natural origin including probiotic Lactobacillus strains have recently attracted a lot of attention.

Methods: After culturing chronic myeloid leukemia cell line K562 in 96-well plates, effects of different concentrations of culture supernatant from Lactobacillus casei on differentiation of the cells were investigated after 40 and 72 hours under an inverted microscope. Number of live cells and percentage of viable cells were determined by trypan blue exclusion test of cell viability. Cytotoxicity was assessed by VTT assay. Data analysis was performed by SPSS (version) 22 using one-way analysis of variance and Tukey's test at significance level of 0.05 .

Results: Secondary metabolites from the probiotic bacteria $L$. casei induced cellular differentiation, exerted anti-cancer effects and inhibited growth in K562 cells. Apoptotic cell death was confirmed by MTT and DNA fragmentation assays in a way that increasing the dilution from 1.2 to 1.32 significantly increased the viability of cells $(\mathrm{P}=0.001)$. In addition, increasing the dilution significantly increased the number of live cells in the first 48 hours $(\mathrm{P}=0.001)$.

Conclusion: Culture supernatant of $L$. casei reduces the number of live cells, and induces apoptosis and monocytic differentiation in K562 cells in a dose- and time-dependent manner. Therefore, combined chemotherapy and differentiation therapy using such supernatants could be useful for treatment of cancer.

Keywords: Cell differentiation, K562 cell line, Probiotic, Lactobacillus casei. 


\section{INTRODUCTION}

Chronic myeloid leukemia (CML) is one of the most recognized forms of leukemia that accounts for $15-20 \%$ of total incidents of this type of cancer. It is more common in people over the age of 50. Philadelphia chromosome is a defect found in $95 \%$ of patients with the disease that results from a balanced translocation between the long arms of chromosomes 9 and 22 (1). This leads to production of $B C R-A B L$ fusion gene that produces an abnormal tyrosine kinase called BCR-ABL, which plays an important role in CML pathogenesis (1). Cells with sustained tyrosine kinase activity do not stop cell division, and become cancerous. The cause of the chromosomal breakage in these cells is unknown (1). Chemotherapy is the most common treatment option for CML. Drugs such as hydroxyurea and busulfan have been able to control the total number of leukocytes, but failed to increase survival in patients. Imatinib is another highly effective drug in treatment of CML that inhibits the abnormal kinase produced by these cells. However, the effect of this drug is reduced due to drug resistance in cancer cells (2). Therefore, many efforts are being made to find novel drugs and anticancer agents. Accordingly, development of new anticancer agents of natural origin has received more attention (3).

Lactobacillus is a genus of probiotic bacteria producing lactic acid as the end-product of carbohydrate fermentation. Lactic acid bacteria are strong prokaryotes with antimicrobial properties. These bacteria are Gram-positive, non-spore-forming, fermentative, catalase-negative, and rodshaped (bacillus) or spherical (coccus). Lactobacillus casei is of great importance in the probiotic food industry, and can interfere with the proliferative and damaging activities of cancer cells by production of various compounds. The main compounds produced by the bacterium are lactic acid, exopolysaccharides, biosurfactants and peptidases (and fewer amounts of hydrogen peroxide, acetic acid, formic acid, and diacetyl) that have anti-cancer effects and play important roles in maintenance and regulation of cell functions. These compounds often have antibacterial, antifungal, antiviral, antiprotozoal and antitumor properties. Some of them are produced in form of supernatant, while some are also structural components of the bacterium. These supernatants are not involved in the growth, proliferation and evolution of bacteria, and are usually produced in the stationary phase of growth (4). In this study, we evaluate the anticancer effects of culture supernatant of this bacterium on K562 cells. The K562 cell line is composed of undifferentiated blast cells that are rich in glycophorin, and derived from chronic myeloid leukemia (CML) patients. The cells were obtained from the Pasteur Institute of Iran. Given that the supernatant derived from Lactobacilli such as $L$. casei has strong antibacterial properties, and the compounds derived from these bacteria have anti-cancer properties (5), we aimed to evaluate the anticancer effects of culture supernatant from L. casei.

\section{MATERIAL AND METHODS}

For bacterial culture and supernatant extraction, lyophilized L. casei (PTCC 1608) were purchased from the industrial fungal and bacterial collection of Iran. To prepare the bacteria, external surface of the ampules was first disinfected with $70 \%$ ethanol, scratched with a diamond scratch pen, and then broken by applying pressure on the scratched area. After addition of $400 \mu \mathrm{l}$ of MRS broth to each ampule, a uniform suspension was achieved by thorough mixing. The suspension was then added to $20 \mathrm{ml}$ of MRS broth. Remaining drops of the suspension were grown on MRS agar medium to ensure the purity of the bacteria. The media containing $L$. casei were incubated at $37{ }^{\circ} \mathrm{C}$ for 48 hours until the end of the stationary phase. Finally, bacteria-free supernatant was used for testing. Batch culture was performed in order to obtain the supernatant. In this technique, no compound is added or removed during fermentation. Therefore, after increase in cell mass and reduction of nutrients, conditions are provided for the production of supernatant. After homogenizing the bacterial suspensions, $4 \mathrm{ml}$ of the suspension was added to $400 \mathrm{ml}(1 \% \mathrm{v}$ : v) of freshly prepared MRS broth, and then incubated at $72{ }^{\circ} \mathrm{C}$ for 72 hours (6). To ensure the entry of bacteria to the stationary phase of growth and production of supernatant, bacterial growth curve was plotted based absorbance at $630 \mathrm{~nm}$. After the incubation time, the number of bacterial colonies was determined in volume unit. The supernatant 
was separated from the culture medium by centrifugation. Due to the high production of lactic acid during the growth and metabolism of $L$. casei that acidify the supernatant extracted, $\mathrm{pH}$ of the suspension was neutralized and adjusted to 7.2-7.4. For this purpose, $1 \mathrm{~N} \mathrm{NaOH}$ solution was used and the final $\mathrm{pH}$ was adjusted to 7.2 at temperature around $0{ }^{\circ} \mathrm{C}$. For sterilization and ensuring the absence of live or dead bacteria debris, 220 micron filters were used.

RPMI 1640 medium enriched with $10 \%$ fetal bovine serum (heat inactivated, Gibco®, USA) was used for the culture of K562 cells. Trypan blue exclusion test of cell viability was used to calculate the percentage of viability according to the following formula (7):

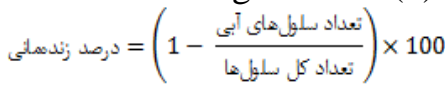

Percentage of viability $=\left(1-\frac{\text { Number of blue cells }}{\text { Number of total cells }}\right) \times 100$

In the next step, the cells were cultured in 96well plates. Cell counting was performed using Neubauer chamber. MTT assay was performed to determine the toxicity of culture supernatant using 1:20 serial dilution.

Cell death or apoptosis was evaluated by Acridine orange staining and fluorescence microscopy. Finally, agarose gel electrophoresis was performed following DNA extraction. Statistical analysis was performed with SPSS (version 22) using one-way analysis of variance and Tukey's test at significance level of 0.05 .

\section{RESULTS}

Total bacterial count

The plates cultured from $10^{-5}$ dilution were selected for counting (the selection was based on presence of 30-300 colonies per plate). Colonies were counted using a colony counter (Digital Colony Counter, Teifazma, Iran). Bacterial density was determined as $\mathbf{1 . 4 9}$ $\times 10^{8} \mathrm{CFU} / \mathrm{ml}$. Figure 1 shows the bacterial growth curve after 72 hours of incubation. Bacteria reached the stationary phase after 50 hours of incubation and produced the supernatant.

Trypan blue exclusion test results

This test was carried out in a 96-well plate. After 48 and 72 hours of incubation, number of cells in each well was counted separately under the Neubauer chamber. Cell viability was $30 \%$ and $9.09 \%$ after 48 hours and 72 hours, respectively. The absorbance values read by the plate reader at $630 \mathrm{~nm}$ are shown in Table 3. Cell viability was determined by comparing the optical density (OD) values of treatment group with those of the control group (100\% viability). Since cell viability at concentration of 1:8 supernatant did not have a significant difference with that of the control group, it was considered as the highest nontoxic concentration.

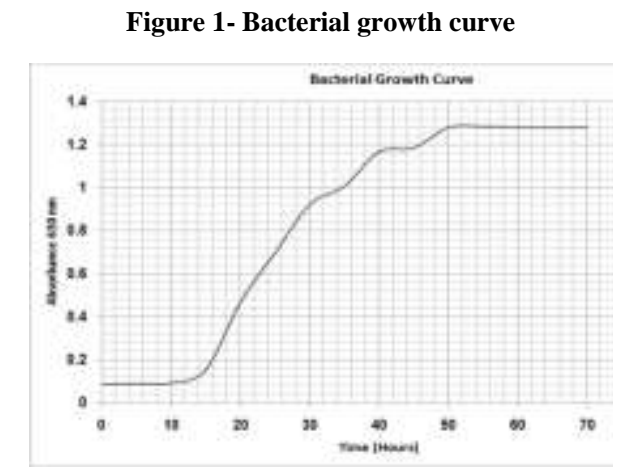

Figure 2- Relationship between dilution and the number of live cells in the first 48 hours

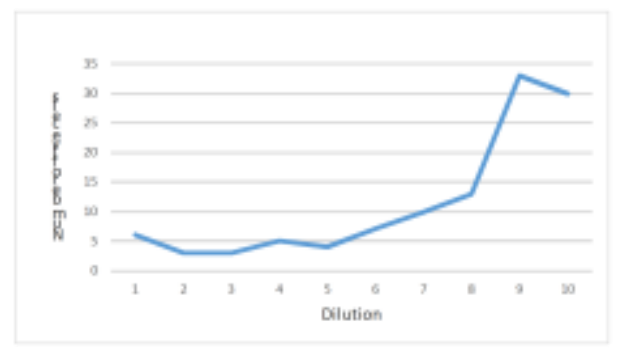


Figure 3- Relationship between dilution and the number of live cells at 72 hours

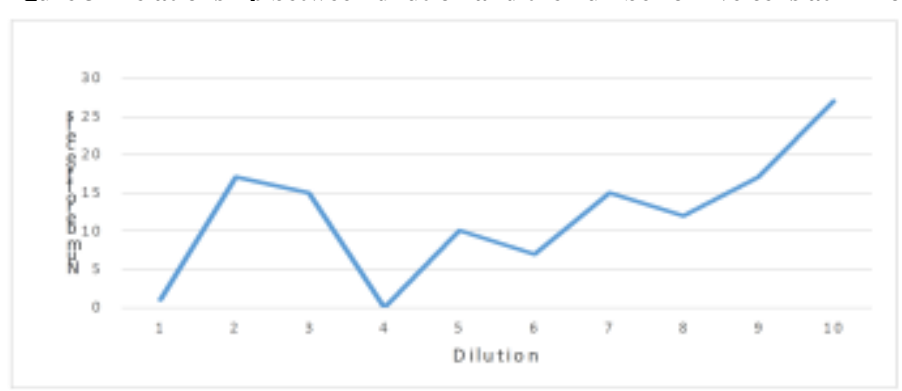

Table 1- Relative cell viability of each well

Dilutions of secondary metabolite

\begin{tabular}{|c|c|c|c|c|c|c|c|c|c|c|c|c|}
\hline \multicolumn{13}{|l|}{ Time } \\
\hline & & $\bar{i}$ & $\dot{i}$ & - & $\dot{\sigma}$ & $\bar{N}$ & $\dot{i}$ & 庨 & $\overline{\tilde{n}}$ & 空 & 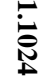 & \\
\hline \multirow{2}{*}{$\begin{array}{c}48 \\
\text { hours }\end{array}$} & Number of dead cells & 14 & 5 & 7 & 8 & 9 & 9 & 7 & 9 & 27 & 22 & 3 \\
\hline & Number of viable cells & 6 & 3 & 3 & 5 & 4 & 7 & 10 & 13 & 33 & 30 & 11 \\
\hline $\begin{array}{c}72 \\
\text { hours }\end{array}$ & $\begin{array}{l}\text { Number of dead cells } \\
\text { Number of viable cells }\end{array}$ & $\begin{array}{c}10 \\
1\end{array}$ & $\begin{array}{l}21 \\
17\end{array}$ & $\begin{array}{l}22 \\
15\end{array}$ & $\begin{array}{l}2 \\
0\end{array}$ & $\begin{array}{c}6 \\
10\end{array}$ & $\begin{array}{l}3 \\
7\end{array}$ & $\begin{array}{c}8 \\
15\end{array}$ & $\begin{array}{l}11 \\
12\end{array}$ & $\begin{array}{l}13 \\
17\end{array}$ & $\begin{array}{l}19 \\
27\end{array}$ & $\begin{array}{l}16 \\
48\end{array}$ \\
\hline
\end{tabular}

Viability (\%) after 48 hours

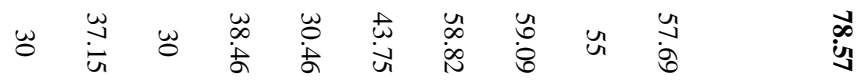

Viability (\%) after 72 hours

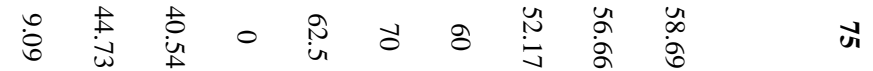

Table 2- Absorbance at $630 \mathrm{~nm}$ (MTT assay)

\begin{tabular}{cccc}
\hline Test group & Supernatant dilution & Mean OD & Relative cell viability (\%) \\
& & & \\
\hline L. casei & $1: 1$ & 0.20325 & 23.82 \\
& $1: 2$ & 0.4455 & 52.21 \\
& $1: 4$ & 0.9475 & 69.70 \\
& $1: 8$ & 0.8165 & 95.69 \\
& $1: 18$ & 0.835 & 97.86 \\
Control & $1: 32$ & 0.83925 & 98.35 \\
& $100 \mu \mathrm{L} \mathrm{PBS}$ & 0.85325 & 100 \\
\hline
\end{tabular}

Figure 4- Relationship between dilution and relative cell viability percentage in the MTT assay

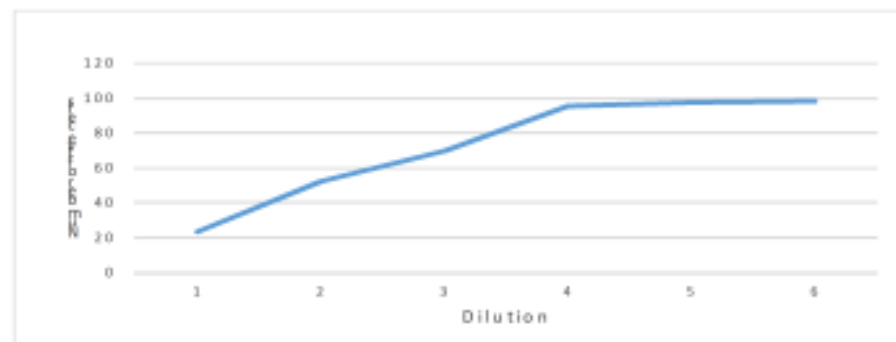


Figure 5- Morphological changes in the $\mathbf{K 5 6 2}$ cells treated with the supernatant under inverted microscope (40X). Comparison of images taken from the $\mathbf{K 5 6 2}$ cells treated with half-maximal inhibitory concentration (IC50) of supernatant with the control (No. 1), and after 24 (No. 2), 48 (No. 3) and 72 (No. 4) hours.
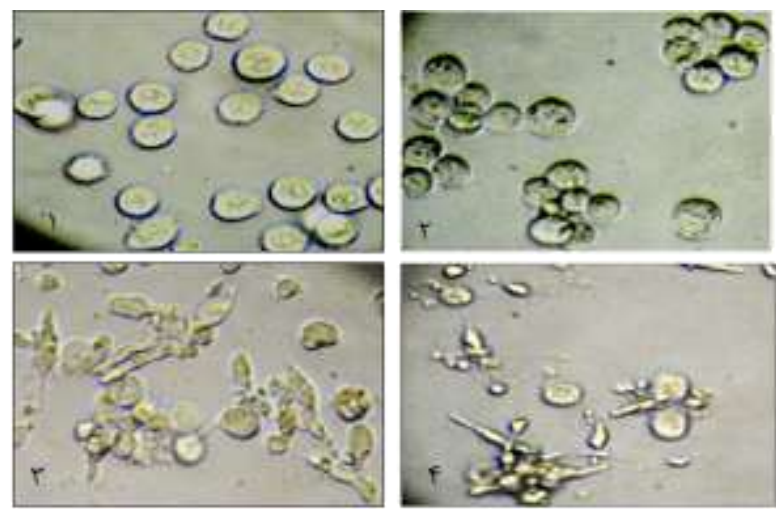

\section{DISCUSSION}

Lactobacillus products have several beneficial effects on balancing the normal activity of different types of blood cells. The most important compounds produced by the bacteria are lactic acid, exopolysaccharides, biosurfactants and peptidases that have direct (cell surface molecules and cell metabolism) or indirect (enzymatic effects on free molecules and those attached to cell membrane) roles in cell function regulation. Study of Iyer et al. on the potential effect of Lactobacillus reuteri on regulation of cell proliferation showed that this bacterium affects cells isolated from myeloid leukemia by inhibiting apoptosis of activated immune cells (8). Study of Puertollano et al. demonstrated that supernatant of Lactobacillus plantarum induces necrosis, which is significantly less than the apoptosis induced in the promyelocytic cell line (9).

Lactic acid-producing probiotic bacteria have anti-cancer effects. In a study on the effects of L. casei and Lactobacillus acidophilus on colon cancer cells, the ability to increase apoptosis in LS513 cell line by the bacteria was evaluated in the presence of 5-fluorouracil (5-FU). The cells were treated with the mentioned bacteria in the presence of $100 \mathrm{mu}$ $\mathrm{g} / \mathrm{ml} \mathrm{5-FU} \mathrm{for} 48$ hours. In the presence of 10 $\mathrm{CFU} / \mathrm{ml}$ of live bacteria, the effect of $5-\mathrm{FU}$ increases up to $40 \%$ in a dose-dependent manner. In addition, rapid activity of caspase3 protein was observed after treatment of cells with the combination of live bacteria and 5-FU. These results indicate that live L. casei and L. acidophilus cells can increase the apoptotic activity of 5-FU. Therefore, probiotics are expected to be used as an adjunct therapy in combination with chemotherapy for treatment of cancer in the future (10).

In another study, rate of proliferation and death of gastric cancer cell line KATO-III was determined after treatment with different doses of $L$. casei extract for different periods. The extract reduced the growth of gastric cancer cells and induced inactivation of NP-kappaB factor. Induction of apoptosis by the $L$. casei extract had no direct correlation with the intrinsic mitochondrial pathway, but reduced the expression of NP-kappa-B and I-kappa-B. The mentioned study was the first to show that the $L$. casei extract induces apoptosis in gastric cancer cells (11). Mousavi et al. investigated the inhibitory and apoptotic effects of carbenoxolone on a human leukemia cell line, and reported that it can inhibit cell growth in a time- and concentration-dependent manner. They reported that the rate of growth inhibition after 48 hours at concentrations of $50,100,150,200,300 \mu \mathrm{M}$ was $79 \%, 59 \%$, $41 \%, 11 \%$, $92 \%$ compared with controls, respectively (12).

In addition, the results of DNA fragmentation assay and fluorescence microscopy indicated the occurrence of apoptosis. Torbati et al. (4) investigated the synthesis and anticancer effects of spiro quinoxaline-pyrazoline on K562 cell line, and reported that the IC50 of the synthesized compound against the K562 cell line and PMBC+PHA cells is 0.92 and $0.75 \mu \mathrm{g} / \mathrm{ml}$, respectively. 


\section{CONCLUSION}

K562 cells can be differentiated into different types of blood cells including erythroid, monocyte-macrophage and megakaryocyte by various compounds. Since leukemia cells stop proliferating at specific stages of their differentiation, it may be possible to either treat or control progression of cancer using drugs that differentiate these cells, and eventually direct them toward apoptosis. Consequently, induction of programmed cell death decreases the risk of recurrence. Moreover, utilizing differentiation therapy along with chemotherapy may increase the drug sensitivity of most cancer cells.

This study evaluated the anticancer effects of L. casei culture supernatant on K562 cells. According to the results, treatment of the K562 cells with the supernatant of $L$. case $i$ induces cancer cell death. The present study is also the

\section{REFERENCES}

1. Bozzone, Donna M. The biology of cancer: Leukemia. New York, Chelsea House pub, 2009.

2. Singhal N, Bapsy PP, Babu KG, George J. Chronic myeloid leukemia. JAPI. 2004; $52: 410-416$.

3. Shin C, Lim H, Moon S, Kim S, Yong Y, Kim B, et al. A novel anti-proliferative agent, phenylpyridineylbutenol, isolated from streptomyces sp. Bioorg Med Chem Lett. 2006; 16(21): 5643-5.

4. Bikhof Torbati M, Shaabanzadeh M, Safari M, Soleymani Ahoee T, Khosravi F. Synthesis and antitumor evaluation of spiro quinoxaline-pyrazoline derivative on K562 cell line. New Cellular and Molecular Biotechnology Journal. 2013; 3(10): 21-26.[Persian]

5. Alidad M, Mohamadi Sani A, Tajali F. Detoxification of Lactobacillus casei as probiotic in Yoghurt. Journal of North Khorasan University of Medical Sciences. 2013; 5(1): 99-106. [Persian]

6. Choi HJ, Kwon DH, Ahn YJ, Baek SH, Song JH. Antiviral activities of cell-free supernatants of yogurts metabolites against someRNA viruses. Eur Food Res Technol. 2009; 228(6): 945-950.

7. Ghanizadeh Vesali S, Zaker F, Zekri A, Ghavamzadeh A, Alimoghaddam K, Ghaffari H. Cytotoxic Effects Of Selective Inhibitor 'Aurora Kinase B' On Viability And Metabolic Features Of Human Promyelocytic Leukemia Cell Line. Journal of payavard salamat. 2013; 7(3): 197 206. [Persian]. first to investigate the cytotoxic effects of $L$. casei supernatant on the K562 cell line. The results of the MTT colorimetric assay show that the new derivatives induce the death of K562 cells in a time- and concentrationdependent manner (i.e. higher concentrations induce more cell death). In addition, 48 hours of treatment with the supernatant causes morphological change and cell destruction. After 72 hours of treatment, cells disintegrate completely, and cell debris become visible.

\section{ACKNOWLEDGMENTS}

The authors would like to express their gratitude to Mr. Mohammad Shadmehri for cooperating in the research project.

\section{CONFLICT OF INTEREST}

All contributing authors declare no conflicts of interest.

8. Iyer C, Kosters A, Sethi G, Kunnumakkara AB, Aggarwal BB, Versalovic J. Probiotic Lactobacillus reuteri promotes TNF-induced apoptosis in human myeloid leukemia-derived cells by modulation of $\mathrm{NF}$ kappaB and MAPK signalling. Cell Microbiol. 2008; 10(7): 1442-1452.

9. Puertollano E, de Cienfuegos GA, Ruiz-Bravo A, de Pablo MA, Puertollano MA. Culture supernatants from lactobacillus plantarum induce necrosis on a human promyelocytic leukemia cell line. Endocr Metab Immune Disord Drug Targets. 2013; 13(2): 195-203.

10. Baldwin C, Millette M, Oth D, Ruiz MT, Luquet FM, Lacroix M, et al. Probiotic Lactobacillus acidophilus and L. casei mix sensitize colorectal tumoral cells to 5fluorouracil-induced apoptosis. Nutr Cancer. 2010; 62(3): 371-378.

11. Hwang JW, Baek YM, Yang KE, Yoo HS, Cho CK, Lee YW, et al. Lactobacillus casei extract induces apoptosis in gastric cancer by inhibiting NF-kappaB and mTOR-mediated signaling. Integr Cancer Ther. 2013; 2(2): 165-173.

12. Moosavi MA, Moasses Ghafary S, Asadi, M, Asvadi Kermani I. Inhibition of survivin and its anti-apoptotic splice variant sur- $\triangle E x 3$ genes expression followed by apoptosis through carbenoxolone in K562 cells. Arak Medical University Journal. 2011; 14(57): 8696.[Persian]. 